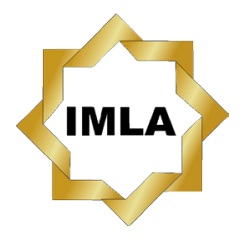

\title{
ANALISIS KESALAHAN SINTAKSIS DALAM BUKU TEKS BAHASA ARAB UNTUK PERGURUAN TINGGI KEAGAMAAN ISLAM
}

\author{
Toto Suharto, Ahmad Fauzi \\ Institut Agama Islam Negeri Surakarta \\ E-mail: tosuh71@gmail.com
}

Naskah diterima: 10 Februari 2017, direvisi: 13 Maret 2017, disetujui: 12 April 2017.

\begin{abstract}
This article described that textbooks used in higher education as a part of the standards of learning material. The learning material did not meet the national standards of higher education if universities did not have a learning material in the form of textbook. One important aspect in writing a textbook was its compliance with grammar. This article attempted to analyze the syntactic errors contained in the textbook, al-Mahir al-Istima fi Tatbiq wa al-Kalam, published by Center of Language Development at IAIN Surakarta. The forms of syntactic errors and the correction of the errors were the focuses of this research. This study used the error analysis. The research found that a syntactic error found in the reading passages were eight forms of errors in isim isyarah (the most one), na'atman'ut, fa'il, isim maushul, jawab syarat, khabar, 'athaf-ma'thuf, and na'ib al-fa'il. Lastly, this textbook was therefore recommended to be revised.
\end{abstract}

Keywords: errors analysis, syntax, Arabic textbook, higher education

\section{Abstrak}

Artikel ini mendeskripsikan bahwa buku teks untuk pembelajaran di perguruan tinggi merupakan bagian dari standar materi pembelajaran. Materi pembelajaran belum memenuhi standar nasional pendidikan tinggi apabila perguruan tinggi tidak memiliki sarana pembelajaran berupa buku teks. Salah satu aspek penting dalam penulisan buku teks adalah kesesuaiannya dengan kaidah gramatikal. Artikel ini bermaksud menganalisis kesalahan sintaksis yang terdapat dalam buku teks, Al-Mahir fi Tathbiq al-Istima' wa al-Kalam, terbitan Pusat Pengembangan Bahasa IAIN Surakarta. Bentuk-bentuk dan pembetulan kesalahan sintaksis merupakan fokus artikel ini. Kajian ini dengan menggunakan pendekatan analisis kesalahan menemukan delapan kesalahan dalam teks bacaan pada isim isyarah (kesalahan terbanyak), na'at-man'ut, fa'il, isim maushul, jawab syarat, khabar, 'athaf-ma'thuf dan na'ib al-fa'il. Terakhir, koreksi terhadap delapan bentuk kesalahan sintaksis tersebut perlu dilakukan dengan menggunakan kaidah gramatikal bahasa Arab standar sehingga buku teks ini direkomendasikan untuk direvisi.

Kata Kunci: analisis kesalahan, sintaksis, buku teks bahasa Arab, perguruan tinggi

How to Cite: Suharto, Toto. Ahmad Fauzi. "Analisis Kesalahan Sintaksis dalam Buku Teks Bahasa Arab untuk Perguruan Tinggi Keagamaan Islam" Arabiyat : Jurnal Pendidikan Bahasa Arab dan Kebahasaaraban [Online], Vol. 4 No. 1 (30 Juni 2017)

Permalink/DOI: http://dx.doi.org/10.15408/a.v4i1.5274 


\section{Pendahuluan}

Buku teks menurut Peraturan Menteri Pendidikan Nasional No. 2 Tahun 2008 tentang Buku, meliputi buku teks pelajaran untuk pendidikan dasar, menengah, dan perguruan tinggi. Buku teks merupakan buku acuan wajib yang digunakan di satuan pendidikan dasar dan menengah atau perguruan tinggi, yang memuat materi pembelajaran dalam rangka peningkatan keimanan, ketakwaan, akhlak mulia, dan kepribadian, penguasaan ilmu pengetahuan dan teknologi, peningkatan kepekaan dan kemampuan estetis, peningkatan kemampuan kinestetis dan kesehatan, yang disusun berdasarkan standar nasional pendidikan. Dengan pengertian ini, buku teks jelas berbeda dengan buku pengayaan, yang diartikan sebagai buku yang memuat materi yang dapat memperkaya buku teks pendidikan dasar, menengah dan perguruan tinggi. Buku teks juga berbeda dengan buku referensi, yang dimaknai sebagai buku yang isi dan penyajiannya dapat digunakan untuk memperoleh informasi tentang ilmu pengetahuan, teknologi, seni, dan budaya secara dalam dan luas. ${ }^{1}$

Keberadaan buku teks bagi proses pembelajaran di perguruan tinggi menjadi penting, sebab merupakan bagian yang tak terpisahkan penggunaannya, yaitu sebagai unsur yang ada dalam standar sarana pembelajaran di perguruan tinggi. ${ }^{2}$ Artinya, sarana pembelajaran di perguruan tinggi belum memenuhi standar nasional pendidikan tinggi apabila perguruan tinggi dimaksud tidak memiliki sarana pembelajaran berupa buku, yang salah satunya adalah buku teks.

\footnotetext{
${ }^{1}$ Peraturan Menteri Pendidikan Nasional RI No. 2 Tahun 2008 tentang Buku, pasal 1.

2 Peraturan Menteri Pendidikan dan Keb dayaan No. 49 Tahun 2014 tentang Standar Nasional Pendidikan Tinggi, pasal 35.
}

Pusat Pengembangan Bahasa IAIN Surakarta merupakan Unit Pelaksana Teknis (UPT) IAIN Surakarta yang memiliki visi "Menjadi pusat pembelajaran, kajian, dan publikasi bahasa serta budaya yang berorientasi pada perubahan sosial". Dengan visi ini, salah satu misi Pusat Pengembangan Bahasa adalah mengembangkan pembelajaran bahasa yang efektif, komunikatif, dan menyenangkan. Dalam konteks ini, Pusat Pengembangan Bahasa merupakan pelaksana Standar Kompetensi Lulusan (SKL) IAIN Surakarta yang terkait dengan kemampuan TOEFL (Test of English as Foreign Language) dan TOAFL (Test of Arabic as Foreign Language) bagi mahasiswa IAIN Surakarta. Untuk melaksanakan SKL ini, Pusat Pengembangan Bahasa mewajibkan bagi mahasiswa baru (Semester I dan II) untuk mengikuti Praktikum Bahasa Arab I dan II, serta Praktikum Bahasa Inggris I dan II. Meskipun praktikum kedua bahasa ini bersifat non-SKS, namun praktikum setiap bahasa memiliki bobot yang setara dengan 6 SKS (dua semester). Di sini, proses praktikum pembelajaran bahasa pada semester I diorientasikan pada penguasaan keterampilan al-istimâ' dan alkalâm untuk Praktikum Bahasa Arab, dan pada penguasaan keterampilan listening dan speaking untuk Praktikum Bahasa Inggris dengan bobot masing-masing setara 3 SKS. Sedangkan praktikum pembelajaran bahasa pada semester II diorientasikan pada penguasaan keterampilan al-qirâ'ah, al-qawâ'id wa al-kitâbah untuk Praktikum Bahasa Arab, dan pada keterampilan reading, grammar and writing untuk Praktikum Bahasa Inggris dengan bobot masingmasing praktikum setara 3 SKS juga. ${ }^{3}$

Terkait dengan proses pembelajaran

3 Silakan akses "Pusat Pengembangan Bahasa" dalam http://www.iain-surakarta.ac.id/?page_ $\mathrm{id}=534$ (diakses pada 26 Maret 2016). 
Praktikum Bahasa Arab untuk mahasiswa semester I yang difokuskan keterampilannya pada al-istimấ dan al-kalâm, Pusat Pengembangan Bahasa telah membuat buku teks Praktikum Bahasa Arab yang diberi judul Al-Mâhir fî Tathbîq al-Istimâ' wa al-Kalâm. Buku teks ini disusun oleh Tim Penulis yang terdiri atas Drs. Abdullah Faishol, M.Hum., H. Ahmad Fauzi, M.A., H. Aminuddin, M.A., Drs. H. Abdul Ghofur, M.Ag., H. Farhan Dhoifur, M.A., Dr. Ja'far Assagaf, M.A., Muhammad Zainuri, S.Pd.I. dan Besut Suryanto, M.Pd.I. Untuk cetakan pertama, buku teks ini terbit pada tahun 2014 (1434 H) dengan ISBN: 978-6027664-58-6, dengan tanpa nama penerbit.

Berdasarkan analisis awal terhadap isi buku teks Al-Mâhir fî Tathbîq al-Istimâ' wa al-Kalâm, didapati beberapa kesalahan sintaksis terkait penulisannya. Di dalam Sambutan Rektor, misalnya, buku teks ini menuliskan: إلى هذه التآليف. Penulisan seperti ini jelas menyalahi kaidah sintaksis Bahasa Arab, sebab antara isim isyarah dan musyar ilaih tidak tepat dari sisi nau' (tazkir-ta'nis)nya. Penulisan bahasa Arab yang benar adalah إلى هذا التآليف. Demikian juga analisis awal menemukan kesalahan sintaksis pada isi buku teks, misalnya di dalam penulisan بجنب عليك إجابتَها adalah merafa'kan kata "إجابَتها", sehubungan posisinya sebagai fa'il. Contoh lain adalah kesalahan sintaksis pada penulisan مات 6. أبو نبيلةَ إسـمُه أحمد، إنتقلت Dalam contoh ini, kesalahan sintaksis terletak pada ketidaktepatan penulisan, sebab yang benar كات أبو مات أبو secara sintaksis bahasa Arab adalah نبيلةَ الذى إسـمُهـ أحسمد، إنتقـلت.

${ }^{4}$ Abdullah Faishol dkk. Al-Mâhir fî Tathbîq alIstimâ' wa al-Kalâm (t.tp.: Pusat Pengembangan Bahasa, 2014), 2.

${ }^{5}$ Abdullah Faishol dkk. Al-Mâhir fî Tathbîq alIstimâ' wa al-Kalâm, 7.

${ }^{6}$ Abdullah Faishol dkk. Al-Mâhir fî Tathbîq alIstimâ' wa al-Kalâm, 10.
Demikian buku teks Al-Mâhir fî Tathbîq al-Istimâ' wa al-Kalâm terbitan Pusat Pengembangan Bahasa IAIN Surakarta, yang merupakan buku acuan wajib yang digunakan untuk Praktikum Bahasa Arab, di dalamnya ditemukan berbagai kesalahan sintaksis yang menyalahi qấidah nahwiyyah bahasa Arab. Sebagai sebuah buku teks yang dipergunakan dalam Praktikum Bahasa Arab, kesalahan sintaksis ini mestinya dihindari, agar penggunaannya oleh pembelajar memiliki daya capaian yang memadai sebagaimana diharapkan. Dari sini, peneliti memandang perlunya dilakukan kajian khusus mengenai analisis kesalahan sintaksis terhadap buku teks Praktikum Bahasa Arab tersebut.

Berdasarkan latar belakang masalah di atas, penelitian ini mempersoalkan adanya kesalahan-kesalahan sintaksis yang terdapat dalam penulisan bahasa Arab buku teks Al-Mâhir fî Tathbîq al-Istimâ' wa al-Kalâm. Masalah pokok yang dikaji dalam penelitian ini adalah: (1) Bagaimana bentuk-bentuk kesalahan sintaksis yang terdapat dalam buku teks Al-Mâhir fî Tathbîq al-Istimâ' wa al-Kalâm? (2) Bagaimana tas\}wi>b\} (upaya membenarkan) atas bentuk-bentuk kesalahan sintaksis yang terdapat dalam buku teks Al-Mâhir fî Tathbîq al-Istimâ' wa al-Kalâm tersebut?

Penelitian ini bertujuan untuk mengungkap bentuk-bentuk kesalahan sintaksis yang terdapat dalam buku teks Al-Mâhir fî Tathbîq al-Istimâ' wa al-Kalâm. Pada saat yang sama, penelitian ini juga bertujuan untuk melakukan tashwîb (upaya membenarkan) atas bentuk-bentuk kesalahan sintaksis yang terdapat dalam buku teks Al-Mâhir fî Tathbîq al-Istimâ' wa al-Kalâm tersebut. Penelitian ini tentu saja diharapkan memiliki kebermaknaan kajian, layaknya sebuah penelitian ilmiah, 
baik teoritis ataupun praktis. Secara teoritis, penelitian ini dimungkinkan menjadi bentuk pengembangan teoritis bagi kaidah-kaidah sintaksis bahasa Arab yang diaplikasikan dalam sebuah buku teks perguruan tinggi. Sebagai buku teks yang dipergunakan dalam pembelajaran bahasa Arab di perguruan tinggi, maka buku teks semacam ini sudah sepatutnya terhindar dari kesalahan-kesalahan sintaksis dalam penulisannya. Analisis kesalahan sintaksis bahasa Arab yang digunakan dalam kajian ini dengan demikian merupakan wujud dari implementasi teoritis atas buku teks bahasa Arab yang digunakan di perguruan tinggi. Inilah kontribusi teoritis yang diharapkan dari penelitian ini. Kemudian secara praktis, penelitian ini diharapkan menjadi bentuk tashwîb (upaya membetulkan) atas bentukbentuk kesalahan sintaksis, yang manfaatnya dapat dirasakan bagi Pusat Pengembangan Bahasa IAIN Surakarta. Dengan demikian, dengan manfaat praktis semacam ini, ke depannya Pusat Pengembangan Bahasa dapat merevisi buku teks Praktikum Bahasa Arab tersebut, agar penulisannya sesuai dengan kaidah-kaidah sintaksis bahasa Arab yang baku.

\section{Metode Penelitian}

Penelitian ini merupakan penelitian kualitatif (qualitative research) dengan menggunakan pendekatan Lingustik Terapan, utamanya bidang analisis kesalahan. Pendekatan ini digunakan untuk: 1) mengidenifikasi, 2) menafsirkan dan 3) melakukan perbaikan terhadap kesalahan-kesalahan linguistik (sintaksis) yang terdapat dalam sebuah buku teks bahasa Arab. Pengumpulan data primer dilakukan dengan teknik dokumentasi dan wawancara. Teknik dokumentasi dilakukan terkait dengan teks bahasa Arab yang terdapat dalam buku teks Al-Mâhir fî Tathbîq al-Istimâ' wa al-Kalâm terbitan Pusat Pengembangan Bahasa IAIN Surakarta. Sedangkan teknik wawancara diperoleh dari wawancara dengan Sekretaris Pusat Pengembangan Bahasa dan salah seorang penulis buku teks. Adapun data sekundernya dikumpulkan dengan teknik dokumentasi, yaitu dengan mengkaji karya-karya yang berbicara tentang analisis kesalahan sintaksis bahasa Arab, baik berupa karya cetak maupun elektronik. Dengan demikian, dalam studi ini, data kepustakaan diperoleh melalui teknik dokumentasi, sedangkan data lapangan dikumpulkan melalui teknik wawancara.

Untuk menguji validitas data, penelitian ini menggunakan teknik triangulasi sumber, ${ }^{7}$ yaitu mengecek keabsahan data yang terdapat dalam dokumen (teks) dengan data hasil wawancara. Adapun metode analisa yang digunakan dalam penelitian ini adalah analisis isi (content analysis), yakni analisis ilmiah tentang isi pesan suatu komunikasi yang tertuang dalam teks atau dokumen. ${ }^{8}$ Data dokumen ataupun wawancara dianalisis kandungan dan isinya, untuk sampai pada suatu kesimpulan yang diambil secara reflektif, yaitu proses mondar-mandir secara cepat antara induksi dan deduksi, antara abstraksi dan penjabaran. ${ }^{9}$

\footnotetext{
7 Sugiyono, Metode Penelitian Pendidikan: Pendekatan Kuantitatif, Kualitatif dan R\&D (Cet. VIII; Bandung: Alfabeta, 2009), 372-373.

${ }^{8}$ Analisis isi secara teknis mencakup upaya kla ifikasi tanda-tanda yang dipakai dalam komunikasi, menggunakan kriteria sebagai dasar klasifikasi, dan menggunakan teknik analisis tertentu sebagai pembuat prediksi. Lihat Noeng Muhadjir, Metodologi Penelitian Kualitatif (Cet. VIII, Edisi III; Yogyakarta: Rake Sarasin, 1998), 49.

${ }^{9}$ Noeng Muhadjir, Metodologi Penelitian Kual tatif, 6.
} 


\section{Hasil Penelitian}

\section{Analisis Kesalahan Sintaksis}

Stephen Pit Corder dipandang pelopor studi analisis kesalahan, yang telah memasukkan analisis kesalahan sebagai bagian dari kajian Linguistik Terapan. ${ }^{10}$ Pada 1967, Corder menulis artikel berjudul "The Significance of Learner's Errors" yang dimuat di International Review of Applied Linguistics. ${ }^{11}$ Di dalam artikel ini Corder menyebut tiga istilah kesalahan, yaitu: (1) kesalahan atau ketergelinciran lisan akibat problem fisik dan atau psikis yang disebut lapses (ketergelinciran lisan), (2) kesalahan sistematis karena kurangnya kompetensi transisional (transitional competence) dalam berbahasa, sehingga menghasilkan kesalahan yang disebut error (kesalahan); dan (3) kesalahan non-sistematis yang bersifat random sehingga menghasilkan mistake (kekeliruan). ${ }^{12}$

Dengan demikian, bagi Corder, ada tiga istilah kesalahan yang perlu dibedakan, yaitu lapses, error dan mistake. Ketiga istilah ini muncul dalam wilayah kesalahan berbahasa. Ketiga istilah ini memiliki domain yang berbeda, sehingga dalam konteks ini perlu dibedakan. Lapses adalah kesalahan berbahasa akibat penutur beralih cara untuk menyatakan sesuatu sebelum seluruh tuturan (kalimat) selesai

${ }^{10}$ Md Noor Hussin dkk., "Analisis Kesalahan Si taksis Buku Teks Bahasa Arab Peringkat Rendah di Sekolah Rendah Agama, Jabatan Agama Islam Selangor (JAIS)", dalam E-Proceeding of the 2nd International Conference on Arabic Studies and Islamic Civilization (ICASIC 2015), pada 9-10 Maret 2015 di Kuala Lumpur, Malaysia, 702.

${ }^{11}$ S. Pit Corder, "The Significance of Learner's Errors", International Review of Applied Linguistics, Vol. 5 (4), 1967, 161-170. Artikel ini dimuat ulang dengan judul yang sama dalam S. Pit Corder, "The Significance of Learner's Errors" dalam Jack C. Richards (ed.), Error Analysis: Perspectives on Second Language Acquisition (London: Longman, 1974), 19-27.

12 S. Pit Corder, “The Significance of Learner's Errors", 166-167. dinyatakan selengkapnya. Untuk berbahasa lisan, jenis kesalahan ini diistilahkan dengan slip of the tongue, sedang untuk berbahasa tulis, jenis kesalahan ini diistilahkan dengan slip of the pen. Kesalahan ini terjadi akibat ketidaksengajaan dan tidak disadari oleh penuturnya. Kemudian error adalah kesalahan berbahasa akibat penutur melanggar kaidah atau aturan tata bahasa. Kesalahan ini terjadi akibat penutur sudah memiliki aturan (kaidah) tata bahasa yang berbeda dari tata bahasa yang lain, sehingga itu berdampak pada kekurangsempurnaan atau ketidakmampuan penutur. Hal tersebut berimplikasi terhadap penggunaan bahasa, yaitu terjadi kesalahan berbahasa akibat penutur menggunakan kaidah bahasa yang salah. Sedangkan mistake adalah kesalahan berbahasa akibat penutur tidak tepat dalam memilih kata atau ungkapan untuk suatu situasi tertentu. Kesalahan ini mengacu kepada kesalahan akibat penutur tidak tepat menggunakan kaidah yang diketahui benar, bukan karena kurangnya penguasaan bahasa kedua. Kesalahan terjadi pada produk tuturan yang tidak benar.

Dalam kajian linguistik bahasa Arab, ketiga istilah di atas diungkapkan dengan bahasa berbeda. Rusydi Ahmad Thu'aimah menyebut ketiganya dengan istilah zillah al-lisân untuk lapses, al-ghalath untuk mistake dan al-khatha' untuk error. Zillah al-lisân adalah kesalahan yang dihasilkan karena kegagapan penutur (taraddud almutakallim). Kemudian al-ghalath adalah kesalahan yang dilakukan penutur karena tuturannya tidak sesuai dengan konteks bahasa. Sedangkan al-khatha' adalah kesalahan yang terjadi karena penutur (mutakallim) atau penulis (kâtib) menyalahi kaidah-kaidah bahasa. Dalam kaitan ini, alkhatha' lebih ditekankan pada penggunaan kaidah bahasa yang salah, terutama dari segi 
pelapalan dan penulisan, karena kurangnya pengetahuan akan watak dan kaidah bahasa Arab, khususnya bahasa Arab fashîhah. Dengan demikian, dapat dikatakan bahwa al-khatha' (error) adalah bentuk bahasa yang dihasilkan penutur atau penulis yang tidak sesuai dengan yang seharusnya, karena terjadi penyimpangan terhadap kaidah-kaidah bahasa Arab yang fasih. ${ }^{13}$

Analisis kesalahan, menurut Jasim Ali Jasim, merupakan perkembangan dalam bidang kajian Linguistik Terapan ('Ilm al-Lughah al-Tathbîqî), yang diterapkan dalam "Pengajaran Bahasa" (Ta'lîm alLughât). Lingustik Terapan bagi kalangan Barat merupakan sesuatu yang baru kemunculannya, yaitu sekitar pertengahan abad ke-20, sementara bagi kalangan Arab merupakan sesuatu yang bukan asing, sebab diperkirakan sudah muncul semenjak abad ke-2 Hijrah. Tokoh-tokoh seperti alKhalil al-Farahidy, Sibawaih, al-Kisai, dan al-Jahidz, merupakan cendikiawan Arab yang sudah bicara tentang teori-teori Lingustik Terapan. Dewasa ini, Lingustik Terapan telah merambah ke berbagai bidang kajian, seperti analisis kontrastif dan analisis kesalahan dalam pembelajaran bahasa, psikolinguistik, sosiolinguistik, neurolinguistik, analisis wacana, dan lainlain. ${ }^{14}$

Dalam pandangan 'Abduh al-Rajihi, analisis kesalahan merupakan langkah lanjutan dari analisis kontrastif, yang merupakan terapan ilmu bahasa dalam pembelajaran bahasa. Lebih jauh, analisis kesalahan merupakan "buah" dari Lingusitik Terapan, yang mencoba mempelajarai

13 Rusydi Ahmad Thu'aimah, Al-Mahârât alLughawiyyah: Mustawayâtuhâ, Tadrîsuhâ, Shu'û-bâtuhâ, (Cet. I; Kairo: Dar al-Fikr al-'Arabi, 2004), 306307.

${ }^{14}$ Jasim Ali Jasim, Al-Tahlîl al-Taqâbulî wa alTahlîl al-Akhthâ' (Cet. I; al-Madinah al-Munawwarah, Maktabah al-Mutannabi': 2015), Pengantar, 5. bahasa yang dihasilkan pembelajar, bukan bahasaitu sendiri. Dalam konteks ini, analisis kesalahan fokus pada dua kajian; kesalahan bagi penutur bahasa, dan kesalahan bagi yang bukan penutur. Kesalahan bagi penutur bahasa lebih diarahkan pada terjadinya kesalahan disebabkan oleh sebab-sebab fisiologi seperti sakit, dan oleh sebab-sebab psikologis semisal gangguan berbicara. Sebab-sebab ini terjadi karena keselo lidah ketika berbicara. Adapun kesalahan bagi yang bukan penutur lebih disebabkan oleh faktor-faktor pembelajaran, dan juga oleh kurangnya pengetahuan akan sistem bahasa yang digunakan. Kurangnya pengetahuan akan sistem bahasa yang digunakan ini meliputi penyimpangan dalam kaidahkaidah sistem bahasa yang dipelajari, baik menyangkut fonologi, morfologi, sintaksis atau semantik. ${ }^{15}$ Dengan demikian, analisis kesalahan sintaksis merupakan salah satu proses menganalisis kesalahan dari segi sintaksis, karena bahasa yang digunakan menyimpang dari aturan sistem sintaknya.

Menurut Muhammad Rajab al-Najjar, kesalahan penulisan Bahasa Arab dalam karya-karya kontemporer terjadi karena kurangnya pengetahuan tentang gramatikal bahasa Arab yang benar, baik menyangkut bentukan kata (morfologis) ataupun susunan kalimat (sintaksis). Dalam konteks ini, penguatan dan penguasaan akan kaidah gramatika bahasa Arab yang benar merupakan hal yang harus diperhatikan, agar terhindar dari kesalahan penulisan tersebut. ${ }^{16}$ Dalam konteks ini, analisis kesalahan dapat digunakan untuk melihat karya-karya yang ditulis dalam bahasa Arab, karena mengalami kesalahan dari segi

15 'Abduh al-Rajihi, 'Ilm al-Lughah al-Tathbîqî wa Ta'lîm al-'Arabiyyah, (Iskandariyah: Dâr al-Ma'rifah al-Jami'iyyah, 1995), 49-50.

16 Muhammad Rajab al-Najjar, Al-Kitâbah al'Arabiyyah: Mahârâtuhâ wa Funûnuhâ, (Kuwait: Maktabah Dar al-'Arubah, 2001), 111. 
sintaksis bahasa Arab.

Dalam analisis kesalahan, terdapat empat wilayah (taksonomi) kesalahan berbahasa, yaitu: taksonomi kesalahan linguistik; taksonomi kesalahan strategi performansi; taksonomi kesalahan komparatif; dan taksonomi kesalahan efek komunikasi. Taksonomi kesalahan linguistik mencakup kesalahan berdasarkan komponen bahasa, yaitu mencakup (1) kesalahan tataran fonologi; (2) kesalahan tataran morfologi dan sintaksis; (3) kesalahan tataran semantik dan kata; dan (4) kesalahan tataran wacana. ${ }^{17}$

Di dalam kesalahan tataran sintaksis, Md Noor Hussin dkk. menemukan tujuh kesalahan sintaksis dalam penulisan buku teks, yaitu: kesalahan penggunaan dlamir, kesalahan penggunaan sifat-mausuf, kesalahan penggunaan mubtada-khabar, kesalahan penggabungan dua kata kerja, kesalahan penggunaan maf'ul bih, kesalahan penggunaan isim ghair munsharif, dan kesaalahan penggunaan tamyiz. ${ }^{18}$ Tujuh bentuk kesalahan sintaksis temuan Md Noor Hussin dkk. ini sifatnya fleksibel. Maksudnya, setiap buku teks memiliki kesalahankesalahan sintaksis tertentu, yang tentunya akan berbeda dengan kesalahan-kesalahan sintaksis pada buku teks lainnya. Oleh karena itu, bentuk kesalahan sintaksis pada sebuah karya belum tentu sama terjadinya pada karya yang lain. Namun yang pasti, kesalahan-kesalahan itu merupakan bentuk kesalahan sintaksis berdasarkan kaidah bahasa tertentu.

Untuk apa melakukan analisis kesalahan? Analisis kesalahan berbahasa

${ }^{17}$ Dian Indihadi, "Analisis Kesalahan Berbahasa" dalam http://file.upi.edu/Direktori/DUAL-MODES/ PEMBINAAN BAHASA_INDONESIA_SEBAGAI_BAHASA KEDUA/10 BBM 8.pdf (temu kembali pada 3 April 2016).

${ }^{18}$ Md Noor Hussin dkk., "Analisis Kesalahan Si taksis Buku Teks", 703-706. perlu dilakukan sebagai bagian dari kajian LinguistikTerapan dalampengajaranbahasa. Thu'aimah mengemukakan empat urgensi analisis kesalahan bagi pengajaran bahasa, yaitu: (1) Analisis kesalahan membekali para pengkaji tentang bagaimana melakukan pengajaran bahasa yang baik, baik dari sisi tata cara pemerolehan bahasa ataupun strategi pengajaran bahasa; (2) Analisis kesalahan dapat menjadi masukan dalam rangka mendesain materi pembelajaran bahasa sesuai bahasa peserta didik; (3) Analisis kesalahan dapat membantu para pengambil kebijakan untuk membuat kurikulum pengajaran bahasa, berdasarkan pada tujuan pembelajaran, pemilihan buku teks, penentuan metode pembelajaran, serta penggunaan teknik penilaian yang tepat; dan (4) Analisis kesalahan memberi peluang untuk melakukan kajian lain terkait kelemahan peserta didik dalam mempelajari bahasa kedua, sekaligus memberinya solusi, sehingga pengajaran bahasa dapat mencapai tujuan. Dengan empat urgensi itu, analisis kesalahan, baik kesalahan ujaran atau kesalahan penulisan, masih menurut Thu'aimah, sering disebut sebagai pascaanalisis (al-tahlîll al-ba'dî), karena analisis kesalahan berupaya mendeskripsikan apa yang sudah terjadi, baik berupa ucapan atau penulisan. ${ }^{19}$ Kondisi ini berbeda dengan analisis kontrastif (al-tahlîll al-taqâbuli>) yang sering disebut pra-analisis (al-tahlîl al-qablî) karena mendeskripsikan ucapan atau penulisan bahasa yang belum terjadi, tapi masih dalam kerangka sistem kedua bahasa yang dianalisis.

$$
\text { Bagaimana analisis kesalahan }
$$
dilakukan? Analisis kesalahan dilakukan mengikuti langkah-langkah tertentu. Rusydi Ahmad Thu'aimah menyebutkan tiga langkah analisis kesalahan. Pertama,

19 Rusydi Ahmad Thu'aimah, Al-Mahârât alLughawiyyah, 307-308. 
mengidentifikasi kesalahan, yaitu langkah mengenal dan membatasi serta mengidentifikasi tempat-tempat terjadinya kesalahan bahasa, yang menyimpang dari kaidah bahasa yang benar. Kedua, mendeskripsikan kesalahan, yaitu menggambarkan dan menjelaskan aspek-aspek kesalahan kaidah bahasa, kemudian mengkategorikannya sesuai tematema kaidah bahasa yang sesuai. Ketiga, menafsirkan kesalahan, yaitu menjelaskan faktor dan sumber kesalahan. ${ }^{20}$

Sementaramenurut'Abduhal-Rajihi,tiga langkahanalisisyangperlu dilakukanadalah: 1) mengidentifikasi dan mendeskripsikan kesalahan; 2) menafsirkan kesalahan; dan 3) melakukan upaya perbaikan kesalahan dan memberinya solusi yang seharusnya. ${ }^{21}$ Dalam konteks ini, langkah yang ditawarkan al-Rajihi kiranya lebih mungkin untuk dilakukan, mengingat ada langkah perbaikan dan solusi yang dapat dilakukan bagi pengkaji analisis kesalahan. Langkah ini penting, untuk mengetahui bagaimana seharusnya kesalahan itu diperbaiki.

\section{Buku Teks}

Pengertian buku teks telah banyak disampaikan oleh para pakar. Berikut dipaparkan beberapa pengertian buku teks sebagaimana dikutip oleh Henry Guntur Tarigan dan Djago Tarigan dalam Telaah Buku Teks Bahasa Indonesia. Menurut HallQuest, buku teks adalah rekaman pikiran rasial yang disusun untuk maksud-maksud dan tujuan-tujuan instruksional. Sementara Lange menjelaskan bahwa buku teks adalah buku standar, buku setiap cabang khusus dan studi, yang dapat terdiri atas dua tipe, yaitu buku pokok/utama dan buku suplemen/

20 Rusydi Ahmad Thu'aimah, Al-Mahârât alLughawiyyah, 308-309.

21 'Abduh al-Rajihi, Ilm al-Lughah al-Tathbîqî wa Ta'lîm al-'Arabiyyah, 50-51. tambahan. Lebih terperinci lagi, Bacon mengemukakan bahwa buku teks adalah buku yang dirancang buat penggunaan di kelas, dengan cermat yang disusun dan disiapkan oleh para pakar atau para ahli dalam bidang itu, dan diperlengkapi dengan sarana-sarana pengajaran yang sesuai dan serasi. Di sisi lain, Buckingham mengatakan bahwa buku teks adalah sarana belajar yang biasa digunakan di sekolah-sekolah dan di perguruan tinggi untuk menunjang suatu program pengajaran dalam pengertian modern, dan yang umum dipahami. Berdasarkan pendapat para ahli tersebut, Tarigan dan Tarigan menyimpulkan bahwa buku teks adalah buku pelajaran dalam bidang studi tertentu, yang merupakan buku standar, yang disusun oleh para pakar dalam bidang tersebut untuk maksud-maksud dan tujuan instruksional, yang diperlengkapi dengansarana-saranapengajaranyangserasi dan mudah dipahami oleh para pemakainya di sekolah-sekolah dan perguruan tinggi, sehingga dapat menunjang suatu program pengajaran. $^{22}$

Penyusunan buku teks dalam upaya pengembangan pembelajaran tidaklah disusun tanpa fungsi yang jelas. Fungsi dan peranan buku teks itu adalah: (a) mencerminkan suatu sudut pandang yang tangguh dan modern mengenai pengajaran serta mendemonstrasikan aplikasinya dalam bahan pengajaran yang disajikan, (b) menyajikan suatu sumber pokok masalah yang kaya, mudah dibaca dan bervariasi yang sesuai dengan minat dan kebutuhan pembelajar, sebagai dasar bagi programprogram kegiatan yang disarankan di mana keterampilan-keterampilan ekspresional diperoleh di bawah kondisi-kondisi yang menyerupai kehidupan yang sebenarnya,

${ }^{22}$ Henry Guntur Tarigan dan Djago Tarigan, $T$ laah Buku Teks Bahasa Indonesia (Bandung: Angkasa, 1986), 11. 
(c) menyediakan suatu sumber yang tersusun rapi dan bertahap mengenai keterampila-keterampilan ekspresional yang mengemban masalah pokok dalam komunikasi, (d) metode dan sarana penyajian bahan dalam buku teks harus memenuhi syarat-syarat tertentu. Misalnya harus menarik, menantang, merangsang, bervariasi sehingga pembelajar benar-benar termotivasi untuk mempelajari buku teks tersebut, (e) menyajikan fiksasi (perasaan yang mendalam) awal yang perlu, dan juga sebagai penunjang bagi latihan-latihan dan tugas-tugas praktis, (f) di samping sebagai sumber bahan, buku teks juga berperan sebagai sumber atau alat evaluasi dan pengajaran remidial yang serasi dan tepat guna.

Buku teks berkaitan erat dengan program kurikulum yang berlaku. Buku teks yang baik harus relevan dan menunjang pelaksanaan kurikulum. Ada sebelas aspek untuk menentukan kualitas buku teks, yaitu (1) memiliki landasan prinsip dan sudut pandang yang berdasarkan teori linguistik, ilmu jiwa perkembangan, dan teori bahan pembelajaran, (2) kejelasan konsep, (3) relevan dengan kurikulum yang berlaku, (4) sesuai dengan minat siswa, (5) menumbuhkan motivasi belajar, (6) merangsang, menantang, dan menggairahkan aktivitas siswa, (7) ilustrasi tepat dan menarik, (8) mudah dipahami siswa, yaitu bahasa yang digunakan memiliki karakter yang sesuai enan tingkat perkembangan bahasa siswa, kalimatkalimatnya efektif, terhindar dari makna ganda, sederhana, sopan dan menarik, (9) dapat menunjang mata pelajaran lain, (10) menghargai perbedaan individu, kemampuan, bakat, minat, ekonomi, sosial dan budaya, (11) memantapkan nilai-nilai budi pekerti yang berlaku di masyarakat

\section{Pembahasan}

\section{Deskripsi tentang Buku Al-Mâhir fî Tathbîq al-Istimâ' wa al-Kalâm}

Buku Al-Mâhir fî Tathbîq al-Istimâ' wa al-Kalâm merupakan buku teks yang digunakan dalam pembelajaran Praktikum Bahasa Arab untuk mahasiswa semester I IAIN Surakarta. Sebagaimana judulnya, buku ini diorientasikan dan berfokus pada pembelajaran Praktikum Bahasa Arab agar mahasiswa semester I memiliki dan menguasai keterampilan al-istimâ' dan alkalâm. Buku teks ini dicetak oleh Pusat Pengembangan Bahasa (Markaz Tathwîr al-Lughât) ${ }^{23}$ IAIN Surakarta pada tahun 2014 dengan ukuran kertas Kwarto A4. Buku teks ini menurut sampul depannya disusun oleh Tim Penulis yang terdiri atas Abdullah Faishol, Aminuddin Ihsan, Tsalis Muttaqin, Abdul Ghofur, Ahmad Fauzi, dan Farhan Dhoifur. Untuk cetakan tahun 2014 (1434 H), buku ini memiliki ISBN: 978-6027664-58-6 yang tertera di sampul belakang, dengan tanpa menyebutkan nama penerbit, hanya mencantumkan Markaz Tat\}wi>r alLugha>t sebagai lembaganya.

Akan tetapi, menurut sampul dalamnya, buku teks ini ditulis oleh para penulis yang terdiri atas: Drs. Abdullah Faishol, M.Hum., H. Ahmad Fauzi, M.A., H. Aminuddin, M.A., Drs. H. Abdul Ghofur, M.Ag., H. Farhan Dhoifur, M.A., Dr. Ja'far Assagaf, M.A., Muhammad Zainuri, S.Pd.I. dan Besut Suryanto, M.Pd.I. Dengan demikian, dari sisi sampul, terdapat nama-nama penulis yang berbeda antara yang tertera di sampul luar dengan sampul dalam buku. Ketika dikonfirmasi, Abdul Ghofur yang selain sebagai Sekretaris Pusat

${ }^{23}$ Pusat Pengembangan Bahasa (Markaz Tat wîr al-Lughât) IAIN Surakarta dulunya adalah Pusat Bahasa dan Budaya. Sejak Statuta 2015 diberlakukan berganti nama menjadi Pusat Pengembangan Bahasa, disingkat P2B. 
Bahasa dan Budaya, juga sebagai salah satu penulis, menuturkan bahwa untuk 2014 ada tambahan penulis, yaitu Dr. Ja'far Assagaf, M.A., Muhammad Zainuri, S.Pd.I. dan Besut Suryanto, M.Pd.I. ${ }^{24}$

Menurut pengakuan Sekretaris Pusat Pengembangan Bahasa (P2B) IAIN Surakarta, buku Al-Mâhir fî Tathbîq alIstimâ' wa al-Kalâm sesungguhnya terbit sejak 2012, kemudian dicetak lagi pada 2013 dan 2014 dengan menambahkan para penulis, yang di antaranya adalah alumni S1 PBA, yaitu Muhammad Zainuri, S.Pd.I. dan Besut Suryanto, M.Pd.I. Dia menambahkan bahwa buku ini ditulis secara tim, dengan membaginya kepada para penulis sesuai pokok bahasannya masing-masing. Setelah ditulis, kemudianbukuinidiselaraskanisinya oleh dia dan Kepala P2B. Setelah itu baru kemudian dicetak dan dipublikasikan. ${ }^{25}$

Salah seorang penulis yang diwawancarai menuturkan bahwa buku ini memang disusun oleh tim penulis. Namun, dia mengakui bahwa setelah ditulis, buku ini tidak sempat diedit lagi. Hal ini karena Ketua P2B ketika itu menghendaki untuk segera dicetak agar dapat dibagikan kepada mahasiswa, sehubungan Praktikum Bahasa Arab segera mulai dilaksanakan. ${ }^{26}$ Berdasarkan informasi ini, maka dapat diketahui bahwa buku teks ini memang setelah disusun dan ditulis, tidak sempat untuk dilakukan proses editing.

Di dalam Sambutan Rektor (Kalimah li Ra'îs al-Jâmi'ah), disebutkan bahwa buku teks Al-Mâhir fî Tathbîq al-Istimâ'

${ }^{24}$ Wawancara dengan Abdul Ghofur, Sekretaris P2B sekaligus salah satu penulis buku teks, pada 29 Juli 2016 di Kantor P2B IAIN Surakarta.

${ }^{25}$ Wawancara dengan Abdul Ghofur, Sekretaris P2B sekaligus salah satu penulis buku teks, pada 29 Juli 2016 di Kantor P2B IAIN Surakarta.

${ }^{26}$ Wawancara dengan Dr. Ja'far Assagaf, M.A., salah seorang penulis buku teks ini, di IAIN Surakarta pada 19 Juli 2016. wa al-Kalâm merupakan buku penting dalam pembelajaran Bahasa Arab, sebagai buku ringkas untuk mempermudah mahasiswa dalam belajar Bahasa Arab. Rektor memandang buku ini sebagai karya sederhana yang bersifat pengantar yang sangat diperlukan bagi mahasiswa, khususnya bagi mahasiswa semester I. oleh karena itu, buku ini merupakan buku wajib (kitâb lâzim) bagi mahasiswa semester I, karena mengandung prinsip-prinsip pembelajaran keterampilan berbahasa Arab. ${ }^{27}$

Sifat ringkas (ikhtisar) buku ini diakui juga oleh Kepala Pusat Bahasa dan Budaya, sebagaimana disebutkan dalam kata pengantarnya sebagai berikut:

"Ini adalah buku al-Mâhir dalam bahasa Arab, yang kami susun untuk disampaikan bagi mahasiswa IAIN Surakarta, seraya memohon semoga Allah memberikan kemanfaatan bagi kami dan saudara-saudara kami, melalui buku ini. Sungguh buku ini telah kami sajikan secara ringkas untuk belajar bahasa (Arab), yang kami nukil (materinya) dari buku al-Arabiyyah bain Yadaik, sebagai rangkaian pembelajaran bahasa Arab bagi para penutur non-bahasa Arab, dari segi keterampilan hiwar, kalam dan qir'oahnya". ${ }^{28}$

Buku teks Al-Mâhir fî Tathbîq al-Istimâ' wa al-Kalâm ditulis dalam 88 halaman dengan memuat 23 pokok bahasan. Ketiga puluh tiga pokok bahasan ini seyogyanya membahas hal-hal yang terkait dengan keterampilan mendengar dan berbicara

27 "Kalimah li Ra'îs al-Jâmi'ah al-Islâmiyyah alHukûmiyyah Surakarta" dalam Abdullah Faishol dkk. Al-Mâhir fî Tathbîq al-Istimâ' wa al-Kalâm, (t.tp.: Pusat Pengembangan Bahasa, 2014), 2.

28 "Muqaddimah" dalam Abdullah Faishol dkk. Al-Mâhir fî Tathbîq al-Istimâ' wa al-Kalâm, (t.tp.: Pusat Pengembangan Bahasa, 2014), 4. 
bahasa Arab, sebagaimana yang menjadi konsen buku teks Al-Mâhir fî Tathbîq alIstimâ' wa al-Kalâm. Namun, ternyata buku ini hanya memberikan keterangan terkait keterampilan mendengar saja, yang disebut dengan fahm al-masmû'. Di dalam buku ini disebutkan bahwa fahm almasmû' adalah untuk menguji kemampuan dalam mendengarkan serta memahami bahasa lisan. Kesulitan yang dihadapi saat mengerjakan fahm al-masmû' biasanya terkait dengan ketidakbiasaan mahasiswa dalam mendengarkan bahasa Arab secara lisan. Untuk itu, buku ini menyarankan agar mahasiswa memiliki fahm al-masmû', mereka harus menguasai kaidah bahasa secara benar, dan memiliki sejumlah kosa kata yang banyak. ${ }^{29}$

Pembelajaran fahm al-masmû' yang menjadi konsen buku ini dilakukan dengan menyajikan empat jenis soal. Keempat jenis soal $^{30}$ ini adalah:

a. Jenis soal al-qism al-awwal, yaitu soalsoal yang memuat pertanyaan untuk mengidentifikasi suara dalam bentuk kalimat yang terdapat dalam kaset.

b. Jenis soal al-qism al-tsânî, yaitu mendengarkan dialog, kemudian mahasiswa diminta untuk memilih jawaban sesuai dialog ini.

c. Jenis soal al-qism al-tsâlits, yaitu mendengarkan dialog, kemudian mahasiswa diminta untuk menjawab soal yang terdapat dalam kaset yang berkaitan dengan dialog tersebut.

d. Jenis soal al-qism al-râbi', yaitu mendengarkan sebuah teks cerita, kemudian mahasiswa diminta menjawab soal yang terkait dengan teks cerita tersebut.

${ }^{29}$ Abdullah Faishol dkk. Al-Mâhir fî Tathbîq alIstimâ' wa al-Kalâm, 5

${ }^{30}$ Abdullah Faishol dkk. Al-Mâhir fî Tathbîq alIstimâ' wa al-Kalâm, 5-7.
Dengan panduan pembelajaran seperti itu, dapat dipastikan bahwa buku teks ini hanya fokus pada keterampilan mendengar dalam bentuk fahm al-masmû', yaitu memahami teks yang didengar. Sesuai fungsinya, buku ini seyogyanya juga berbicara mengenai panduan pembelajaran untuk keterampilan berbicara (kalam). Namun buku ini kiranya belum menyentuh keterampilan berbicara ini, meskipun dari judulnya dan sebagaimana yang menjadi program Praktium Bahasa Arab, bahwa juz awal buku ini diorientasikan pada pengembangan keterampilan mendengar dan berbicara bagi mahasiswa semester I IAIN Surakarta.

\section{Bentuk-Bentuk Kesalahan}

Berdasarkan analisis sintaksis terhadap dokumen buku Al-Mâhir fî Tathbîq al-Istimâ' wa al-Kalâm juz 1, ditemukan beberapa kesalahan yang perlu dicermati. Kesalahankesalahan ini penulis temukan dalam teksteks bacaan, yang tidak berkaitan dengan soal atau pertanyaan yang diajukan. Berikut dikemukakan kesalahan-kesalahan sintaksis tersebut:

a. إلى هذه التآليف (hlm. 2). Di sini isim isyarah هذه diikuti musyar ilaih mudzakkar, yaitu kata k التآليف.

b. في أسلوب سهـلة (hlm. 2). Kata أسلوب yang سهلة mudzakkar di sini disifati oleh kata yang mu'annats.

c. جتب عليك إجابتَها (hlm. 7). Kata إجابتَها di sini dibaca manshub yang menjadi fa'il bagi kata تجب.

d. مات أبو نبيلًَ إسمُمه أحمد، إنتقلت (hlm. 10).

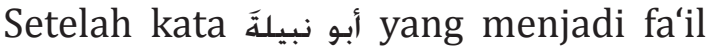
kata مات, langsung diikuti anak kalimat إسـُمَه أحمد , tanpa isim maushul sebagai kata sambung di antara dua kalimat.

e. وأمَّا سعيدةٌ في المصلى تصلي Jhlm. 15). Kata syarat أمَّا di sini tanpa diikuti fa' jawab. 
f. السـاعةُ الآن السـادسةَّ صباحًا (hlm. 31). Kata di sini dibaca manshub yang menjadi khabar bagi kata السـاعةُ هذاعة

g. الجُوُ معتدلّ هذهِ الأيَّامِ (hlm. 43). Kata هذِهِ الأيّاٍٍ majrur.

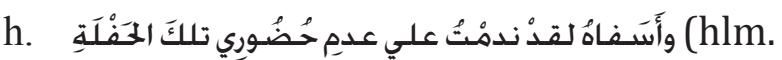
82). Kata الحَفْلَفِ di dini dibaca majrur yang menjadi badal bagi isim isyarah تلكَ yang kedudukannya sebagai maf'ul manshub bagi mashdar حُضُورئ.

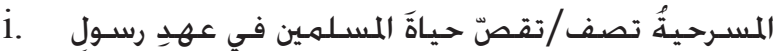

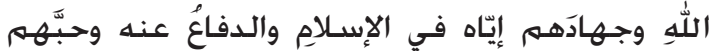
إيَّاه (hlm. 84). Kata الدفاع الإعاع dini dibaca حياة yang manshub.

j. تُعَقَدُ الحفلةَ في قاعِة الجامعتِِ (hlm. 86). Kata الحفلةَّ di sini dibaca manshub yang kedudukannya sebagai naib fa'il bagi kata kerja تُعْقَد.

Demikian sepuluh kesalahan sintaksis yang ditemukan dalam buku teks AlMâhir fî Tathbîq al-Istimâ' wa al-Kalâm juz 1. Kesepuluh kesalahan ini apabila dikategorisasi maka dapat diklasifikasikan dalam delapan bentuk kesalahan sebagai berikut:

1) Bentuk kesalahan sintaksis dalam penulisan isim isyarah. Ini terdapat pada kesalahan nomor 1 , nomor 7 dan nomor 8.

2) Bentuk kesalahan sintaksis dalam penulisan na'at-man'ut. Bentuk kesalahan ini terdapat dalam kesalahan nomor 2.

3) Bentuk kesalahan sintaksis dalam penulisan fa'il. Bentuk kesalahan ini ditunjukkan oleh kesalahan nomor 3 .

4) Bentuk kesalahan sintaksis dalam penulisan anak kalimat yang menggunakan isim maushul. Bentuk kesalahan ini terdapat pada kesalahan nomor 4.
5) Bentuk kesalahan sintaksis dalam penulisan jawab syarat. Bentuk kesalahan ini terdapat pada kesalahan nomor 5 .

6) Bentuk kesalahan sintaksis dalam penulisan khabar. Bentuk kesalahan ini dapat ditunjukkan pada kesalahan nomor 6.

7) Bentuk kesalahan sintaksis dalam penulisan 'athaf-ma'thuf. Bentuk kesalahan ini terdapat pada kesalahan nomor 9.

8) Bentuk kesalahan sintaksis dalam penulisan na'ib al-fa'il. Bentuk kesalahan ini dapat ditemukan pada kesalahan nomor 10.

\section{Tashwîb atas Bentuk-bentuk Kesalahan}

Bagaimana delapan bentuk kesalahan itu dibetulkan? Oleh karena kedelapan kesalahan penulisan yang terdapat dalam buku teks Al-Mâhir fî Tathbîq al-Istimâ' wa al-Kalâm juz 1 itu bersifat sintaksis, yang berkaitan dengan kaidah nahwu bahasa Arab, maka pembetulan (tashwîb) tentu saja didasarkan pada kaidah-kaidah nahwu yang benar.

Berikut ini dikemukakan pembetulan (tashwîb) atas delapan bentuk kesalahan sintaksis yang ditemukan dalam buku teks Al-Mâhir fî Tathbîq al-Istimâ' wa al-Kalâm juz 1. Sebagai pedoman, buku yang digunakan sebagai dasar pembetulan dalam kajian ini adalah Mulakhkhash Qawâ'id al- Lughah al-'Arabiyyah karya Fu'ad Ni'mah. Buku ini dijadikan pedoman karena buku ini sering digunakan sebagai rujukan bagi perkuliahan bahasa Arab, baik di Indonesia ataupun negara-negara Timur Tengah. Menurut penulisnya, buku ini disusun sebagai rujukan bagi siapa saja yang mempelajari bahasa Arab, yang dengan buku ini mereka akan terbantu untuk menguasai kaidah bahasa 
Arab, sekaligus dapat menghindarkan mereka dari kesalahan-kesalahan sintaksis dan linguis yang terdapat dalam beragam karya tulis berbahasa Arab. ${ }^{31}$

1. Pembetulan bentuk kesalahan isim isyarah. Isim isyarah adalah isim mabni yang menunjukkan pada sesuatu yang tertentu dengan cara memberinya petunjuk. Dalam kaidah bahasa Arab, isim isyarah digunakan untuk kata tunjuk jauh dan kata tunjuk dekat. Untuk kata tunjuk dekat, sebelum isim isyarah didahului Hâ al-Tanbîh, contoh هذا untuk mudzakkar atau هذه untuk muannats. Sedangkan untuk kata tunjuk jauh, setelah isim isyarah diikuti Kâf atau Kâf dan Lâm, seperti. تلك ذالك ذان Selain هذان dan هاتان, semua isim isyarah adalah mabni, diberi i'rab sesuai kedudukannya dalam kalimat. Apabila isim yang jatuh setelah isim isyarah itu diawali alif dan lam, maka isim yang jatuh setelah isim isyarah ini diposisikan sebagai badal (pengganti), yang i'rabnya mengikuti i'rab isim isyarahnya. ${ }^{32}$ Dengan demikian, penulisan teks bacaan yang benar secara sintaksis adalah:

a. إلي هذا إلي هذا التأليف,bukan ألتيف, karena kata التأليف adalah mudzakkar.

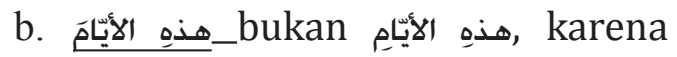
posisi isim isyarah dan musyar ilaihnya di sini sebagai dzaraf zaman, yang menerangkan waktu terjadinya udara normal.

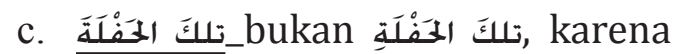
menjadi maf'ul bih manshub dari mashdar yang beramal seperti fi'ilnya, yaitu kata حُضُوري.

${ }^{31}$ Fu'ad Ni'mah, Mulakhkhash Qawâ'id al-Lughah al-'Arabiyyah, (Cet. IX; Beirut: Dar al-Tsaqafah al-Islamiyyah, t.t.), 5.

${ }^{32}$ Fu'ad Ni'mah, Mulakhkhash Qawâ'id al-Lughah al-'Arabiyyah, 121-122.
2. Pembetulan bentuk kesalahan na'atman'ut. Na'at adalah isim pengikut yang menunjukkan kata sifat bagi kata sebelumnya. Na'at terbagi dua; hakiki dan sababi. Na'at hakiki adalah sifatyang menunjukkan sifat bagi diri yang diikuti, sedangkan Na'at sababi adalah sifat bagi isim yang memiliki hubungan dengan yang disifati. Untuk Na'at hakiki, wajib mengikuti yang diikuti dari segi nakirahma'rifat,jumlah, dan tadzkir-ta'nitsnya. ${ }^{33}$ Jadi, apabila yang disifati mudzakkar, maka na'atnya harus mudzakkar pula. Oleh karena itu, penulisan teks bacaan أسـلوب yang benar secara sintaksis adalah

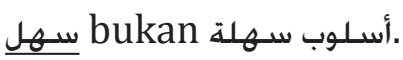

3. Pembetulan bentuk kesalahan fa'il. Fa'il adalah isim marfu' yang jatuh setelah fi'il mabni ma'lum dan menunjukkan kepada si pelaku perbuatan atau pelaku yang memiliki sifat perbuatan tersebut. Antara fi'il dan fa'ilnya tidak mesti berada dalam posisi yang beriringan. Di antara keduanya boleh dipisah oleh kata lain sebagai pemisah, yang penting adalah dibaca marfu'. ${ }^{34}$ Dengan demikian, penulisan teks bacaan yang طنب عenar secara kaidah nahwu adalah علبك عليك إجابتُها.

4. Pembetulan bentuk kesalahan dalam penulisan anak kalimat yang seharusnya menggunakan isim maushul. Di dalam kaidahbahasaArab,untukmembuatanak kalimat dapat dilakukan salah satunya dengan penggunaan isim maushul (kata penyambung dua kalimat; induk kalimat dan anak kalimat). Isim maushul adalah isim mabni yang menunjukkan pada sesuatu tertentu dengan menggunakan perantara (wâsithah) anak kalimat

${ }^{33}$ Fu'ad Ni'mah, Mulakhkhash Qawâ'id al-Lughah al-'Arabiyyah, 51-52.

${ }^{34}$ Fu'ad Ni'mah, Mulakhkhash Qawâ'id al-Lughah al-'Arabiyyah, 42-45. 
yang terletak setelahnya, yang disebut shilah al-maushûl. Shilah al-maushûl ini bias berupa kalimat ismiyyah, kalimat fi'liyyah atau syibh al-jumlah (jar majrur atau dzaraf-madzruf). Khusus untuk shilah al-maushûl yang berupa kalimat ismiyyah dan kalimat fi'liyyah, kalimat ini harus mengandung dhomir (kata ganti) yang menghubungkan jumlah ini dengan isim maushul, dan harus sesuai dari sisi tadzkir-ta'nits dan dari sisi bilangannya. ${ }^{35}$ Oleh karena itu, pembetulan teks bacaan yang

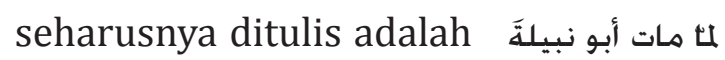

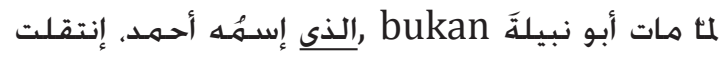

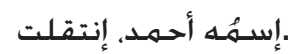

5. Pembetulan bentuk kesalahan jawab syarat. Di dalam bahasa Arab terdapat sejumlah gaya bahasa (uslub) yang dibuat dengan susunan tertentu, di antaranya adalah uslub syarat. Gaya bahasa syarat merupakan uslub yang tersusun dari perangkat syarat yang menghubungkan dua kalimat; kalimat syarat dan jawab syarat. Salah satu perangkat syarat adalah huruf ammâ, yaitu huruf tafdhil yang menempati pada kalimat syarat, yang untuk kalimat jawabnya harus menggunakan fâ aljawâb. ${ }^{36}$ oleh karena itu, penulisan teks وأمَّا سـعيدةً ففي bacaan yang benar adalah وأمَّا سـعيدةً في المصلى فصي تصلي bukan المصلى تصلي

6. Pembetulan bentuk kesalahan khabar. Khabar merupakan sesuatu yang dapat menyempurnakan makna mubtada, yaitu bagian yang dapat menyusun kalimat efektif bersama mubtada. Khabar harus sesuai dengan mubtada dari segi bilangan dan jenisnya (tadzkir-

${ }^{35}$ Fu'ad Ni'mah, Mulakhkhash Qawâ'id al-Lughah al-'Arabiyyah, 123-125.

${ }^{36}$ Fu'ad Ni'mah, Mulakhkhash Qawâ'id al-Lughah al-'Arabiyyah, 176-177. ta'nits). Khabar bisa terdiri atas isim dhahir, jumlah (ismiyyah dan fi'liyyah) dan syibh jumlah (jar majrur dan dzarafmadzruf). Khabar yang berasal dari isim dhahir, maka harus dibaca marfu', sedangkan untuk khabar yang berasal dari jumlah (ismiyyah dan fi'liyyah) dan syibh jumlah (jar majrur dan dzarafmadzruf), maka kerafa'an khabarnya berada pada jumlah mahalliyah, yaitu khabar marfu' dari segi posisinya dalam kalimat. ${ }^{37}$ Oleh karena itu, penulisan teks bacaan yang benar adalah السـاعُّة

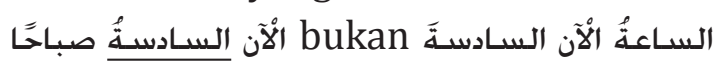
( ) مباحًا

7. Pembetulan bentuk kesalahan 'athafma'thuf. 'Athaf merupakan pengikut, yang antara pengikut dan yang diikuti diantarai oleh salah satu huruf 'athaf. Karena 'athaf ini masuk kategori pengikut, maka i'rabnya mengikuti yang diikuti. Huruf 'athaf ada sembilan, salah satunya adalah waw yang memiliki makna mengumpulkan (al-jam') antara yang diikuti dengan pengikutnya. ${ }^{38}$ Oleh karena itu, penulisan teks bacaan yang benar secara sintaksis adalah: المسرحية تصف/تقصّ حباةَ المسـلمين في عهدِ رسـولِ اللهِ

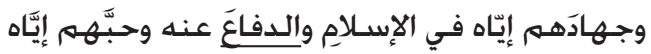

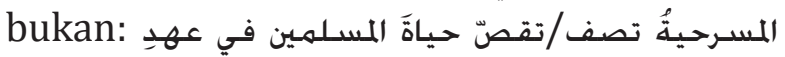

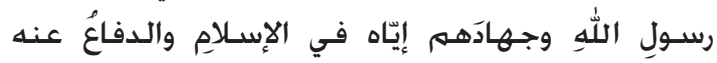
. وحبَّهـهم إيَّاه

8. Pembetulan bentuk kesalahan na'ib al-fa'il. Na'ib al-fa'il adalah isim yang dibaca rafa' yang jatuh setelah fi'il mabni majhul. Na'ib al-fa'il sebenarnya menempati posisi fa'il, setelah fa'ilnya dibuang. Pembuangan fa'il ini dilakukan karena sudah diketahui atau belum diketahui. Kata kerja bahasa Arab ada

${ }^{37}$ Fu'ad Ni'mah, Mulakhkhash Qawâ'id al-Lughah al-'Arabiyyah, 30-32.

${ }^{38}$ Fu'ad Ni'mah, Mulakhkhash Qawâ'id al-Lughah al-'Arabiyyah, 53-54. 
kalanya berupa muta'adi (transitif) atau lazim (intransitif). Ketika kata kerja itu transitif, kemudian subjek fa'ilnya dibuang, maka objek yang disebut maf'ul bih ini posisinya menjadi na'ib al-fa'il. ${ }^{39}$ Oleh karena itu, penulisan teks

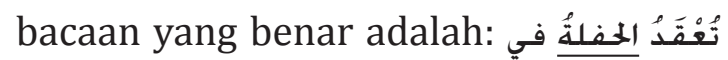

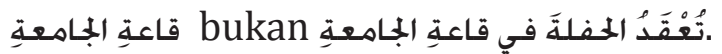
Untuk dapat mengetahui bentuk-bentuk kesalahan di atas dengan jelas, berikut dikemukakan tabel kesalahan penulisan secara sintaksis dan pembetulannya: tiga kesalahan, sementara bentuk kesalahan lainnya hanya memuat satu kesalahan sintaksis.

\section{Analisis atas Kesalahan Sintaksis dalam Buku Teks Al-Mâhir fî Tathbîq al-Istimâ' wa al-Kalâm Juz 1}

Buku teks dalam sebuah pembelajaran sangat diperlukan keberadaannya. Buku teks merupakan buku acuan wajib yang digunakan di satuan pendidikan tertentu, mulai pendidikan dasar dan menengah, hingga perguruan tinggi.

Tabel 1. Bentuk Kesalahan Sintaksis dan Pembetulannya

\begin{tabular}{|c|c|c|c|}
\hline No & Bentuk Kesalahan & Kesalahan Sintaksis & Pembetulan Sintaksis \\
\hline 1. & Isim Isyarah & إلى هذه التأليف & إلى هذا التأليف \\
\hline & Isim Isyarah & هذَهِ الأيَّامِ & هذَهِ الأيّاَحَ \\
\hline & Isim Isyarah & تلكَ الحَفْلَةِة & تلكَّ الحَفْلَةً \\
\hline 2. & Na'at-Man'ut & أسلوب سهلَة & أسلوب سهل \\
\hline 3. & Fa'il & تجب عليك إجابتها & تجب عليك إجابتها \\
\hline 4. & Tidak ada Isim Maushul & إنتقلت مات أبو نبيلةً إسمُمها أحمد، & إنتا مات أبو نبيلةً الذى إسمُمه أحمد، \\
\hline 5. & Jawab Syarat & وَأمَّا سعيدةُ في المصلى تصلي & وأمَّا سعيدةٌ ففي المصليى تصلي \\
\hline 6. & Khabar & 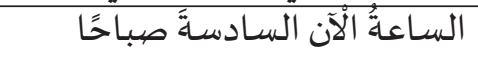 & 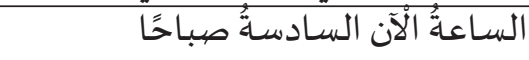 \\
\hline 7. & 'Athaf-Ma'thuf & 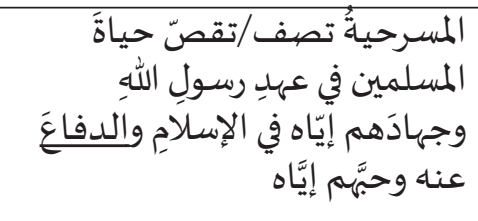 & 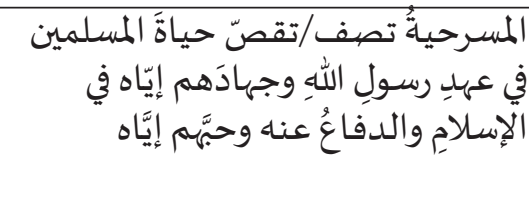 \\
\hline 8. & Na'ib al-Fa'il & 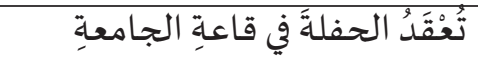 & 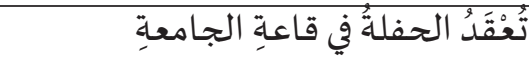 \\
\hline
\end{tabular}

Dari tabel di atas dapat diketahui bahwa kesalahan sintaksis yang terdapat dalam teks bacaan yang terdapat dalam buku teks Al-Mâhir fî Tathbîq al-Istimâ' wa al-Kalâm juz 1 meliputi delapan bentuk kesalahan sintaksis, yaitu bentuk isim isyarah, na'atman'ut, fa'il, kekurangan isim maushul, jawab syarat, khabar, 'athaf-ma'thuf, dan na'ib al-fa'il. Dari delapan bentuk kesalahan ini, kesalahan sintaksis terbanyak terletak pada penulisan isim isyarah, yaitu berjumlah

\footnotetext{
${ }^{39}$ Fu'ad Ni'mah, Mulakhkhash Qawâ'id al-Lughah al-'Arabiyyah, 47-48.
}

Buku teks ini memuat materi pembelajaran dalam rangka pencapaian tujuan pembelajaran. Karena buku teks berbeda dengan buku pengayaan dan buku referensi, maka buku teks seyogynya terhindar dari segala kesalahan, baik kesalahan kebahasaan ataupun kesalahan non-kebahasaan. Hal ini penting, karena buku teks merupakan unsur terpenting bagi standar sarana pembelajaran, apalagi untuk jenjang pendidikan tinggi. Artinya, sarana pembelajaran di perguruan tinggi belum memenuhi standar nasional pendidikan 
tinggi, apabila perguruan tinggi dimaksud tidak memiliki sarana pembelajaran berupa buku, yang salah satunya adalah buku teks. Ketika buku teks yang digunakan mengandung unsurkesalahan, maka standar sarana pembelajaran dalam perguruan tinggi tersebut menjadi "ternodai".

Buku teks Al-Mâhir fî Tathbîq al-Istimâ' wa al-Kalâm Juz 1 merupakan buku teks terbitan Pusat Bahasa dan Budaya IAIN Surakarta tahun 2014, dalam rangka pembelajaran Praktikum Bahasa Arab untuk mahasiswa semester I. Setelah dilakukan analisis kesalahan sintaksis, ternyata buku teks ini memuat delapan bentuk kesalahan sintaksis. Kesalahan penulisan dalam sebuah buku teks mungkin saja terjadi. Akan tetapi, sebaiknya ini dihindari, terutama apabila kesalahan ini terjadi pada buku teks perguruan tinggi.

Diakui salah seorang tim penulisnya memang buku teks Al-Mâhir fî Tathbîq al-Istimâ' wa al-Kalâm Juz 1 belum sempat dilakukan proses editing, meski menurut Sekretaris P2B sudah dilakukan penyelarasan. Proses editing terhadap sebuah naskah yang hendak dicetak perlu dilakukan, untuk mengetahui kualitas isi buku tersebut. Setelah editing, sebaiknya juga dilakukan proof reading, yaitu direview oleh ahli bahasa, sehingga diketahui kekurangannya. Proses-proses ini kiranya belum dilakukan terhadap buku teks AlMâhir fî Tathbîq al-Istimâ' wa al-Kalâm Juz 1. Meski dengan alasan segera dicetak karena hendak segera dipergunakan, buku teks yang bermutu tetap harus memperhatikan unsur-unsur kebahasaaannya, sehingga terhindar dari kesalahan kebahasaan dalam penulisannya. Untuk itu, tim penulis, kalau memang dibuat oleh sebuah tim, sebaiknya mempersiapkan secara matang mengenai materi buku teks yang akan dicetak, terutama dari sisi kebahasaannya.

Kesalahan kebahasaan yang terdapat dalam buku teks membuat buku teks tersebut menjadi berkurang kualitasnya. Meskipun kesalahan itu sedikit dan bersifat teknis, tetapi kesalahan ini menjadi “aib” bagi buku teks tersebut, yang untuk kemudian pada gilirannya dapat mengganggu pada proses pembelajaran, saat buku itu digunakan dalam proses pembelajaran. Untuk mengejar kualitas buku teks, alasan "proyek" seyogyanya tidak diterapkan dalam proyek penulisan buku teks, apalagi buku teks tersebut diperuntukkan bagi jenjang perguruan tinggi. Lebih buruk lagi apabila kesalahan kebahasaan ternyata ditemukan juga dalam buku teksyang hendak digunakan untuk pembelajaran bahasa. Ini sesuatu yang ironis. Bagaimana bisa, sebuah buku teks pembelajaran bahasa mengandung kesalahan penulisan dari sisi kebahasaan! Ini tentu saja sangat mengurangi kualitas suatu buku teks pembelajaran bahasa.

Untuk itu, dalam penulisan buku teks pembelajaran bahasa, sebaiknya dilakukan koordinasi kebahasaan yang matang di antara tim penulis. Koordinasi ini menjadi penting, untuk menjadikan buku teks pembelajaran bahasa ini sebagai buku teks yang bermutu. Tidak perlu tergesa-gesa untuk dicetak, bila perlu didatangkan para reviewer yang memang ahli dalam bahasa tersebut.

\section{Simpulan}

Setelah data dokumen dan wawancara dikumpulkan yang kemudian dianalisis isinya, kajian tentang analisis kesalahan sintaksis pada penulisan buku teks AlMâhir fî Tathbîq al-Istimâ' wa al-Kalâm Juz 1 dapat disimpulkan dalam dua poin sebagai berikut: 
1. Kesalahan sintaksisyang terdapat dalam teks bacaan yang terdapat dalam buku teks Al-Mâhir fî Tathbîq al-Istimâ' wa al-Kalâm juz 1 meliputi delapan bentuk kesalahan sintaksis, yaitu bentuk isim isyarah, na'at-man'ut, fa'il, kekurangan isim maushul, jawab syarat, khabar, 'athaf-ma'thuf, dan na'ib al-fa'il. Dari delapan bentuk kesalahan ini, kesalahan sintaksis terbanyak terletak pada penulisan isim isyarah, yaitu berjumlah tiga kesalahan, sementara bentuk kesalahan lainnya hanya memuat satu kesalahan sintaksis.

2. Pembetulan terhadap delapan kesalahan sintaksis di atas dilakukan dengan memperhatikan kaidah sintaksis bahasa Arab yang baku. Oleh karena itu, kesalahan sintaksis, baik bentuk isim isyarah, na'at-man'ut, fa'il, kekurangan isim maushul, jawab syarat, khabar, 'athaf-ma'thuf, ataupun na'ib al-fa'il, yang terdapat dalam teks bacaan buku teks Al-Mâhir fî Tathbîq al-Istimâ' wa alKalâm juz 1, dibetulkan sesuai dengan kaidah sintaksis bahasa Arab ini.

Analisis kesalahan terhadap buku teks Al-Mâhir fî Tathbîq al-Istimâ' wa al-Kalâm Juz 1 memunculkan beberapa rekomendasi. Pertama, kesalahan penulisan dalam sebuah buku teks mungkin saja terjadi. Akan tetapi, sebaiknya ini dihindari, terutama apabila kesalahan ini terjadi pada buku teks perguruan tinggi. Meski dengan alasan segera dicetak karena hendak segera dipergunakan, buku teks yang bermutu tetap harus memperhatikan unsur-unsur kebahasaaannya, sehingga terhindar dari kesalahan kebahasaan dalam penulisannya. Kedua, tim penulis sebaiknya mempersiapkan secara matang mengenai materi buku teks yang akan dicetak, terutama dari sisi kebahasaannya.
Kesalahan kebahasaan yang terdapat dalam buku teks membuat buku teks tersebut menjadi berkurang kualitasnya. Meskipun kesalahan itu sedikit dan bersifat teknis, tetapi kesalahan ini menjadi "aib" bagi buku teks tersebut, yang untuk kemudian pada gilirannya dapat mengganggu pada proses pembelajaran, saat buku itu digunakan dalam proses pembelajaran. Ketiga, dalam penulisan buku teks pembelajaran bahasa, sebaiknya dilakukan koordinasi kebahasaan yang matang di antara tim penulis. Koordinasi ini menjadi penting, untuk menjadikan buku teks pembelajaran bahasa ini sebagai buku teks yang bermutu. Tidak perlu tergesa-gesa untuk dicetak, bila perlu didatangkan para reviewer yang memang ahli dalam bahasa tersebut. Keempat, kajian ini baru sebatas melihat kesalahan dari sudut sintaksis terhadap buku teks Al-Mâhir fî Tathbîq al-Istimâ' wa al-Kalâm Juz 1. Perlu kajian lanjutan terhadap buku teks Al-Mâhir Juz 2 yang memuat keterampilan Qawa'id dan Kitabah. Selain itu, analisis selain sintaksis, baik morfologis atau semantik, dapat dilakukan terhadap buku teks ini.[]

\section{Daftar Rujukan}

Abdul Ghofur, Wawancara Pribadi, Sekretaris P2B dan penulis buku teks, IAIN Surakarta pada 29 Juli 2016.

Corder, S. Pit. "The Significance of Learner's Errors”, International Review of Applied Linguistics, Vol. 5 (4), 1967, hlm. 161170.

Corder, S. Pit. “The Significance of Learner's Errors" dalam Jack C. Richards (ed.), Error Analysis: Perspectives on Second Language Acquisition. London:Longman, 1974.

Faishol, Abdullah, dkk. Al-Mâhir fî Tathbîq al-Istimâ' wa al-Kalâm Juz 1, t.tp.: Pusat Pengembangan Bahasa, 2014. 
Hussin, Md Noor, dkk., "Analisis Kesalahan Sintaksis Buku Teks Bahasa Arab Peringkat Rendah di Sekolah Rendah Agama, Jabatan Agama Islam Selangor (JAIS)", dalam E-Proceeding of the 2nd International Conference on Arabic Studies and Islamic Civilization (ICASIC 2015), pada 9-10 Maret 2015 di Kuala Lumpur, Malaysia.

Indihadi, Dian "Analisis Kesalahan Berbahasa" dalam http://file.upi.edu/ Direktori/DUAL-MODES/PEMBINAAN BAHASA INDONESIA SEBAGAI BAHASA KEDUA/10 BBM 8.pdf (temu kembali pada 3 April 2016).

Jasim, Jasim Ali. Al-Tahlîll al-Taqâbulî wa al-Tahlîl al-Akhthâ' : al-Nazhariyyah wa al-Tathbîq. Cet. I; al-Madinah alMunawwarah, Maktabah al-Mutannabi': 2015.

Muhadjir, Noeng. Metodologi Penelitian Kualitatif. Cet. VIII, Edisi III; Yogyakarta: Rake Sarasin, 1998.

al-Najjar, Muhammad Rajab. Al-Kitâbah al'Arabiyyah: Mahârâtuhâ wa Funûnuhâ. Kuwait: Maktabah Dâr al-'Arubah, 2001.

Ni'mah, Fu'ad. Mulakhkhash Qawâ'id alLughah al-'Arabiyyah. Cet. IX; Beirut: Dar al-Tsaqafah al-Islamiyyah, t.t.
Peraturan Menteri Pendidikan dan Kebudayaan No. 49 Tahun 2014 tentang Standar Nasional Pendidikan Tinggi.

Peraturan Menteri Pendidikan Nasional RI No. 2 Tahun 2008 tentang Buku. al-Rajihi, 'Abduh, 'Ilm al-Lughah al-Tathbîqî wa Ta'lîm al-'Arabiyyah. Iskandariyah: Dar al-Ma'rifah al-Jami'iyyah, 1995.

Assagaf, Ja'far. Wawancara Pribadi. Penulis Buku Teks, IAIN Surakarta, pada 19 Juli 2016.

Sugiyono. Metode Penelitian Pendidikan: Pendekatan Kuantitatif, Kualitatif dan R\&D. Cet. VIII; Bandung: Alfabeta, 2009. Tarigan, Henry Guntur dan Tarigan, Djago. Telaah Buku Teks Bahasa Indonesia. Bandung: Angkasa, 1986.

Tim Penyusun, "Pusat Pengembangan Bahasa" dalam http://www.iain-surakarta.ac.id/?page_id=534 (diakses pada 26 Maret 2016).

Thu'aimah, Rusydi Ahmad. Al-Mahârât al-Lughawiyyah: Mustawayâtuhâ, Tadrîsuhâ, Shu'û-bâtuhâ. Cet. I; Kairo: Dar al-Fikr al-'Arabi, 2004.

Wawancara dengan Abdul Ghofur, Sekretaris P2B sekaligus salah satu penulis buku teks, pada 29 Juli 2016 di Kantor P2B IAIN Surakarta. 